\title{
Production of Vegetable Protein in Changing Climate
}

\section{Janusz Prusinski*}

Department of Agriculture and Biotechnology, University of Science and Technology in Bydgoszcz, Poland

*Corresponding author: Janusz Prusinski, Professor, Department of Agriculture and Biotechnology, University of Science and Technology in Bydgoszcz, Poland, Tel: 52 374-94-51; E-mail: prusin@utp.edu.pl

Received date: September 22, 2017; Accepted date: September 26, 2017; Published date: Octoberber 03, 2017

Copyright: ( 2017 Prusinski J. This is an open-access article distributed under the terms of the Creative Commons Attribution License, which permits unrestricted use, distribution, and reproduction in any medium, provided the original author and source are credited.

\section{Introduction}

Global warming and climate changes and their effects on human life, and agriculture, is one of substantial challenges faced by Humans. The temperature of air when increased result in escalated evaporation and the evolution of new areas of drought, decreased plant vegetation time, effortless existence of pathogens and pests and, this results in decreased production of many crops even to 5 to 10 percent. Considering the global warming and negative phenomena of weather we can expect more and more difficulty in crop yield conditions due to inadequate water retention, non-cost-effective technologies of agriculture and irrigation, increased production costs. Production of plant protein in Europe is quite hard, so UE, also Poland is mostly dependent on soybean protein coming from GMO cultivars, mainly from South America.

What is the most important issue to meet the demands of the above mentioned changes in the production of vegetable protein?

\section{Biological Progress in European Pulses}

Pulses are an important part of agriculture and food systems all over the world, but their productivity in Europe is low and stagnant. Meanwhile, over the past 30 years, average grain yields of cereals have been increased by $100 \%$, mainly due to biological progress.

In 2013, the UN General Assembly reported the 2016 International Year of Pulses. The main objective of the UN action is to raise public awareness of the benefits of incorporating legumes into cropping patterns, human and animal nutrition and food security in the world, and their importance for the environment and sustainable development.

At present, there is significant imbalance in the production and availability of plant protein - its major global producers are USA and South America, and consumers (importers) - China and Europe. It is estimated that the increase of relatively low-priced legumes in countries suffering from malnutrition or starvation (Latin America, Africa and Asia) can bring about 100 million people out of poverty by 2030.

At present at the European Commission Common Catalogue of Varieties of Agricultural Plant Species in the Official Journal of the European Union there are 1080 cultivars of pulses, including 331 of Pisum sativum L., 397 of Glycine max. L/ Merr., 126 of Vicia faba L., and 118 of Vicia sativa L. (also 44 of Lupinus angustifolius L., 26 of Vicia villosa L., 21 of Lupinus albus L., 13 of Lupinus luteus L. and 4 of Vicia pannonica L.). Present share of legumes in the sowing structure in the $\mathrm{EU}$ is from 0.5 to $6.5 \%$, and is still going down, whereas other than Europe it is $15-25 \%$ and is still increasing. In the near future, it is difficult to believe that EU countries will give up GMO soybean meal. It is to be assumed that any diversification of vegetable protein sources will have an impact on increasing the food safety of animal products and the continuity of feed supply.

It is important not to succumb to the general high quality and usefulness of soybean meal, as the weight gain of animals using peas, bean or lupine protein feeds will be smaller, however local and global benefits coming from legumes to Poland and the EU may be equally important in the future. Also, it is not possible to treat soybean meal as a panacea for all protein dietary problems, but overall GMO soybean resignation currently for conventional soybean (and more expensive GMO) and/or legume protein does not seem possible without significant deterioration in farmers' financial performance and raise prices of products of animal origin. While many EU countries are introducing GMO bans, none of them plans to give up soybean meal derived from GMO varieties.

\section{Intensification of Legume Production}

Production of leguminous plants, keeping aside numerous benefits for soil environment, may contribute to decreasing the deficit of plant protein and the present common import of plant protein in Europe. Legumes are particularly useful in many parts of the world in the conservation agriculture, which results from their ability to symbiotically fix $\mathrm{N}$, supplying large amount of organic matter owing to a high $\mathrm{N}$ to $\mathrm{C}$ ratio and breaking the life cycle of many pathogens. Agro economic problems in legume production are various depending on the quarter of the world, even though utmost preference in decreasing the yield is given to water deficiency and biotic stresses, while other factors such as increased temperature or lack of nutrients usually play a minor role. Correct agricultural procedures applied in legumes almost completely include plant requirement for $\mathrm{N}$ provided that there are strains of active symbiotic bacteria in the soil.

When compared with the low-input technology, application of industrial production means (mineral fertilization with $\mathrm{N}, \mathrm{P}$ and $\mathrm{K}$ as well as crop-protection preparations) in medium- and high-input technologies allow to increase productivity of legume species. It should be considered groundless to apply additional chemical treatment in high-input technology.

\section{Winter/Autumn Legumes}

Winter forms of legumes which, other than a longer biomass accumulation, establish an active use of post-winter water, more bountiful and - faster than in spring forms - developed root system in early spring - should make it possible to avert adverse effects of May semi-droughts and water deficiency over fruit and seed setting (the third decade of May to the end of the third decade of June). Many professionals call for sowing winter cereal cultivars wherever possible, exclusively in the areas of low total rainfall. To do so, there are also used new facultative spring cereal cultivars, mostly wheat and triticale 
Page 2 of 2

which, when sown in late autumn after beet or corn, or even over the pre-winter period (passed the agronomic sowing date for winter forms), at a mild and sowing-enhancing weather, start vegetation in spring earlier, cover the soil better and yield higher than the ones sown at the spring date.

In Western Europe for example in Spain, France, Italy, warmer parts of Switzerland, Germany and England, and white lupin winter seed forms of pea and faba bean can be grown. Yield and its stability of spring cultivars of legumes are strongly dependent on climate especially on rainfall distribution, while other factors, such as an increased temperature or lack of nutrients, typically play a lesser role. Winter/overwintering forms, beside a longer period of assembling biomass, are described by a more active usage of post-winter water, while their better and quicker developed root system in early spring than in spring forms, and also flowering earlier by 3-4 weeks allow for avoiding adverse effects of dry spells in May and water deficiencies in the stage of developing pods and seeds, as well as antagonistic effects of high temperature in June, attributable to which they give higher and more stable yields than spring forms.

In many European countries, among other things in Spain, Germany, Great Britain, France, Italy, Romania, Turkey, as well as e.g. in the USA winter/overwintering forms of field pea, faba bean and/or white lupine have been the subject of continuous research. Sowing date and developmental stage in which plants enter winter dormancy season, as well as the occurrence and thickness of snow cover decide their resistance to lesser temperature, overwintering and yield potential. Overwintering and yield of other cultivars of winter field pea from the Common Catalogue should be investigated for cultivation across the Europe, the ones with higher resistance to a low temperature during winter dormancy, e.g. cultivars from Germany, Russia, Czech Republic, Finland or Lithuania than the ones from regions located in the significantly lower latitude.

It is commonly believed that the current lesser importance of legumes in plant protein balance in Europe mostly results from lesser fertility and low yield stability of that plant group. The new legumes seed production solutions proposed call for further research and concern sowing, in late-autumn, of winter or spring forms applying special treatments protecting plants in winter and pre-winter sowing specially protected from imbibition of spring legume cultivars seeds. The main objective of the technologies intended is to create conditions for fast rooting and appearance of plants in spring and a better use of post-winter water prior to the instance of unfavourable moisture conditions in May, and frequently also in June, when they are most sensitive to water deficit.

\section{The After-Effect of Chosen Fabaceae Forecrops}

The Fabaceae are designed to be a perfect forecrop in cereal monocultures. Their important advantage is fixing $\mathrm{N}$ in the soil and not losing its resources for successively grown plants, as well as interrupting the life cycle of pathogens, especially in cereals, owing to a wide ratio of $\mathrm{N}$ to $\mathrm{C}$ of organic matter from the post-harvest residues left after harvest. Moreover, most Fabaceae plants root deeply, contributing to the cycle of nutrients and successful use of water by successively grown plants, and decreasing their dependence of yielding on inorganic, especially under conditions of reduced mineral $\mathrm{N}$ fertilization. Grain yields of cereals cultivated after leguminous forecrops may be higher by $0.5-1.8$ t.ha- 1 than after cereal plants, which indicate possible decrease in mineral $\mathrm{N}$ rates under successively grown plants without a significant decrease in the yield or problems caused by weeds and pathogens. Most of $\mathrm{N}$ fixed by leguminous plants is removed with production; however the rest becomes available for the successively grown plants owing to which protein yield in cereal grain may also be much higher in the successively grown plants. Therefore application of mineral fertilization with $\mathrm{N}$ rates from 60 to $180 \mathrm{~kg} \mathrm{~N} / \mathrm{ha}$ did not significantly vary the average grain yield of winter triticale. The content of Nmin in the layer of $0-60 \mathrm{~cm}$ after harvesting leguminous forecrops fertilized with mineral $\mathrm{N}$ was by $25.5 \%$ higher than after harvesting spring barley, under which $60 \mathrm{~kg} \mathrm{~N} /$ ha was applied before sowing. The difference in the Nmin content left after triticale cultivated after spring barley and leguminous forecrops along with an increase in the rates of mineral $\mathrm{N}$ from 0 to $180 \mathrm{~kg} \mathrm{~N} / \mathrm{ha}$ did not exceed $22.5 \mathrm{~kg}$ $\mathrm{N} / \mathrm{ha}$, probably due to a higher use of soil $\mathrm{N}$ by triticale than mineral $\mathrm{N}$. Under conditions of low-intensity agriculture with no or low rates of the applied $\mathrm{N}$, cereal cultivation after leguminous plants guarantees obtaining at least average yields of winter triticale, whereas applying more than $60 \mathrm{~kg} \mathrm{~N} / \mathrm{ha}$ has no justification.

\section{White Lupin}

Feed protein deficit in Europe and Poland tends to seek opportunities for a greater use of native protein sources for substitution or a partial supplementation of imported soybean meal. White lupin among other Fabaceae species could serve as an alternative source for protein in the climatic conditions of Poland and Europe. Lupin seed yields depend on the use of industrial production means. In practice, the choice of a particular technology on the farm is largely determined by economic evaluation of its effectiveness. The EU Catalogue includes twenty two species from nine European countries. Presently, white lupin has the highest seed yield potential among lupin species. However, its disadvantage is the significant susceptibility to anthracnose. Modern cultivation of lupin uses the genetic material of available cultivars and wild forms as well as natural and induced mutation in order to increase genetic variation. The world is carried on a small scale study on developing forms of GMOs and the use of heterosis in lupin. So far no positive results had also obtained using interspecies hybrids. A small natural intraspecific variability and implemented to a limited extent modern methods of biotechnology and molecular cytogenetics (micropropagation, somatic embryogenesis, protoplast culture, transformation, androgenic etc.), in vitro cultures etc. create a significant barrier in the biological progress in lupin. The important goals in white lupin cultivation are also resistant to drought and anthracnose, seed quality, abortion of flowers, buds and pods, as well as seeking the thin walls of the pod and seed coat and of sources of genetic resistance to Phomopsis sp.In spite of significant achievements in lupin genetics, the cultivation and breeding methods are mainly based on the use of genetic resources of cultivars already in use. 